\title{
INCIDENCE OF PRESUMPTIVE SALMONELLA IN POULTRY MEAT PRODUCTS
}

\section{MOHAMED KARMI}

Department of Food Hygiene, Faculty of Veterinary Medicine, Aswan University, 81528 Aswan, Egypt. Corresponding author: Mohamed Karmi,

Email: Karmy99@yahoo.com, mkarmi@aswu.edu.eg

\section{ABSTRACT}

Received at: 12/10/2013

A total of 50 poultry meat products samples were collected from shops and supermarkets in Aswan province; 10 samples chicken luncheon; 10 samples chicken burger; 10 samples smoked turkey; 10 samples livers \& gizzard and 10

Accepted: 15/12/2013 samples sheeshtawook. Samples were investigated for the presence of salmonella by using bacteriological and biochemical tests. It was observed that $10 \%(1 / 10)$ of livers \& gizzard and 20\% (2/10) of sheeshtawook; $0 \%(0 / 10)$ of chicken luncheon; $0 \%(0 / 10)$ of chicken burger; $0 \%(0 / 10)$ of smoked turkey were positive for salmonella. Salmonella contamination was found in livers \& gizzard and in sheeshtawook while chicken luncheon, chicken burger and smoked turkey were free from salmonella. Some poultry meat products especially products which consists of raw meat material such as livers \& gizzards or products which not subjected to sufficient cooking considered an important source for salmonella infection. Poultry meat products manufactured in food factories apply good hygiene practices are free from salmonella contamination. Strategies to reduce salmonella levels on raw poultry should be undertaken to improve the safety of poultry products and reduce the incidence of human salmonellosis from poultry consumption.

Keywords: Salmonella, poultry meat, chicken, products, contamination.

\section{INTRODUCTION}

Salmonella is a gram negative rod, non-lactose fermenter, facultative anaerobic, non-spore forming, mesophilic heterotrophs, produce acid and gas from glucose, belonging to the family Enterobacteriaceae, are classified and identified into serotypes according to the Kauffmann-White scheme 7, which currently contains more than 2000 serotypes (Williams and Wilkins, 1984).

Salmonella is one of the most commonly reported causes of food-borne disease in the Worldwide and show the highest disease burden on the population scale among bacterial food-borne pathogens (Franz et al., 2012; Hanning et al., 2009). Ninety-seven percent of food samples were contaminated with at least one enteric pathogen, salmonella is one of the most commonly isolated pathogen about $84 \%$. Fiftyone percent of children infected with salmonella, infected with the same serotypes isolated from meat samples, suggesting this pathogen is widespread in food and humans (Bodhidatta et al., 2013). In 2007 Austria reported a total of 438 food borne outbreaks, salmonella caused $70 \%$ of the bacterial outbreaks and the most implicated food was the poultry meat products (Much et al., 2009). Strong associations were found between contamination of poultry meat and poultry meat products with salmonella and some factors such as production system, number of birds per flock, feeding system, slaughterhouse, storage condition, retail store type, poultry company, and socioeconomic conditions. Chickens from a nonintegrated poultry company were associated with a significantly greater risk of salmonella contamination than chickens from an integrated company (DonadoGodoy et al., 2012).

Strains of Salmonella isolated from poultry products are strongly associated with multi-locus sequence type ST28 and showed antimicrobial multi-resistance profiles, so that poses a health risk to consumers (Toboldt et al., 2012). Pulsed-field gel electrophoresis (PFGE) results confirmed occurrence of similar Salmonella genotypes in both poultry meat products and humans, also, antimicrobial drug resistance profiles suggesting possible transmission of resistance from meat to humans (Oloya et al., 2009). In the last two decades, Salmonella enterica serotype Enteritidis has become one of the main agents causing food borne diseases worldwide. This agent is transmitted mainly by contaminated meat and poultry products (88\%), suggesting strong relationships between cases of Salmonella related to human illness and Salmonella positive in meat and poultry products (Rios et al., 2009; Chen et al., 2008; Pang et al., 2007). 
The same multi-drug resistant Salmonella infantis clone was spread from the examined broiler farms contaminating the slaughter and the retail meat and appeared in the human illnesses of the examined region that was earlier detected as the dominant clone characteristic of the broiler and human population of the whole country (Nogrady et al., 2008). Preventive hygienic measures and strategies were suggested to minimize the incidence of Salmonella contamination of broiler chicken and chicken products such as acidification of feed and drinking water with organic acids, immune strategies based on passive and active immunity, modification of diet by changing ingredients and compositions, food additives as antibiotics, prebiotics, probiotics and symbiotic, cooking methods and good hygienic practices during preparation and manufacture (Vandeplas et al., 2010). Treatment of poultry meat products with $1.0 \%$ antimicrobials reduced Salmonella to non-detectable levels in stored frozen products (Moschonas et al., 2012).

\section{MATERIALS and METHODS}

Collection of samples: 50 poultry meat products samples were collected from retailers and markets in Aswan province. 10 samples were collected from each product; chicken luncheon, chicken burger, smoked turkey, livers \& gizzards and sheeshtawook. Samples were collected in sterile polyethylene bags, put in ice tank under low temperature and transported to the laboratory for bacteriological examination.

Preparation of samples: Twenty-five grams meat were taken from each poultry meat product sample in sterile stomacher bag, mixed with $225 \mathrm{ml}$ buffered peptone water (BPW) (Co, Oxoid Limited,
Hampshire, England) and homogenized by using Stomacher® 400 Circulator (Co, Seward Ltd., UK).

Isolation and Identification: The samples mixtures incubated at $37 \pm 2{ }^{\circ} \mathrm{C}$ for $18 \pm 0.2$ hours, $0.1 \mathrm{ml}$ mixturewas transferred to $10 \mathrm{ml}$ RappaportVassiliadis (RV) medium,vortexed andincubatedfor $24 \pm 2 \mathrm{~h}$ at $42 \pm 0.2^{\circ} \mathrm{C}$ (circulating, thermostaticallycontrolled, water bath). $3 \mathrm{~mm}$ loopful $(10 \mu \mathrm{l})$ of each incubated tube was streaked on Xylose Lysine Desoxycholate (XLD) agar and incubated for $24 \pm 2$ $\mathrm{h}$ at $35^{\circ} \mathrm{C}$. Typical colonies of salmonella were pink colonies with or without black centers. Many cultures of salmonella may produce colonies with large, glossy black centers or may appear as almost completely black colonies. Salmonella isolates were confirmed by biochemical tests asTriple Sugar Iron agar (TSI), Lysine decarboxylase (LIA), Urease, Indole, Methyl red, Voges-Proskauer and Simmons citrate (AOAC, 2000; Ewing, 1986; June et al., 1995; Hammack et al., 1999; June et al., 1999; Hammack et al., 2001).

\section{RESULTS}

Results of this study showed that incidence of presumptive salmonella in poultry meat products was $6 \%$. It was observed that $10 \%(1 / 10)$ of livers \& gizzard and $20 \%(2 / 10)$ of sheeshtawook; $0 \%(0 / 10)$ of chicken luncheon; $0 \%(0 / 10)$ of chicken burger; $0 \%(0 / 10)$ of smoked turkey were positive for presumptive salmonella. Salmonella contamination was found in livers \& gizzard and in sheeshtawook while chicken luncheon, chicken burger and smoked turkey were free from salmonella (Table 1).

Table 1: Incidence of Salmonella in poultry meat products.

\begin{tabular}{|c|c|c|c|c|c|}
\hline \multirow{3}{*}{ Meat Type } & \multirow{3}{*}{ No. of Samples } & \multicolumn{4}{|c|}{ Salmonella } \\
\hline & & \multicolumn{2}{|c|}{ Positive } & \multicolumn{2}{|c|}{ Negative } \\
\hline & & No. & $\%$ & No. & $\%$ \\
\hline Chicken luncheon & 10 & 0 & 0 & 10 & 100 \\
\hline Chicken burger & 10 & 0 & 0 & 10 & 100 \\
\hline Smoked turkey & 10 & 0 & 0 & 10 & 100 \\
\hline Livers \& gizzards & 10 & 1 & 10 & 9 & 90 \\
\hline Sheeshtawook & 10 & 2 & 20 & 8 & 80 \\
\hline Total & 50 & 3 & 6 & 47 & 94 \\
\hline
\end{tabular}




\section{DISCUSSION}

The overall incidence of salmonella in poultry meat products was $6 \%$. Incidence rate of salmonella differs variably in poultry meat products; chicken luncheon, chicken burgers and smoked turkey samples were free from salmonella while $10 \%$ of livers \& gizzards and $20 \%$ of sheeshtawook samples were positive for Salmonella. The results of overall incidence of salmonella in poultry products agreed with some other studies such as Madden et al., 5.1\% (Madden et al., 2011), White et al., 4.3\% (White et al., 2007), Oscar, 3\% (Oscar, 2013) and lower than other results such as Ta et al., 45.9\% (Ta et al., 2012), Alali et al., $31.5 \%$ (Alali et al., 2012), Fearnley et al., 38.8\% (Fearnley et al., 2011), Dione et al., 40.4\% (Dione et al., 2009), Vindigni et al., 61\% (Vindigni et al., 2007). Our results of salmonella contamination in livers \& gizzards and in sheeshtawook were 10 and $20 \%$, respectively, agreed with similar results such as Busani et al., 9.9\% (Busani et al., 2005), Raufu et al., 15\% (Raufu et al., 2009) and Mikanatha et al., 22\% (Mikanatha et al., 2010).

Results showed higher incidence rate of salmonella in livers \& gizzards and in sheeshtawook and freedom of chicken luncheon, chicken burgers and smoked turkey, these findings can be attributed to cooking and hygienic measures adopted during production and preparation of these products. Raw or undercooked poultry meat products such as livers \& gizzards and raw chicken meat, insufficiently cooked sheeshtawook, nuggets, strips and microwave-cooked products considered as infection vehicles for salmonella and these products may pose an infection risk if the products is improperly cooked (Domingues and Schaffner, 2009; Smith et al., 2008). Freedom of Salmonella in chicken luncheon, chicken burger and smoked turkey could be partly due to heat treatment during manufacture and partly due to the presence of chemical preservatives (Waters et al., 2011; Bennet et al., 1986).

Growth and inactivation of salmonella in poultry meat products are highly influenced by temperature after controlling for other factors (Smadi et al., 2012). Outbreaks of salmonellosis associated with raw, frozen and undercooked chicken products and the infection were 11 times higher in individuals who had consumed frozen processed chicken products (MacDougall et al., 2004). Fresh poultry meat especially edible organs are the dominant sources of the detected salmonella than other samples (Trajkovic-Pavlovic et al., 2007). A significant difference in salmonella occurrence between meat type and sampling month, also, salmonella from raw turkey exhibited higher antimicrobial resistance (53\%) compared to those from ready-to-eat products (Khaitsa et al., 2007).
Overall $80.9 \%$ of broiler processing establishments were positive for salmonella and fail to meet the salmonella performance standard (Elben et al., 2006). Application of hygienic approaches and effectiveness of potential interventions during production, slaughtering, manufacturing, preparation and processing of poultry meat products can significantly reducing the number of salmonella positive samples in poultry meat products (Van Der Fels-Klerx et al., 2008).

\section{CONCLUSION}

Some poultry meat products especially products which consists of raw meat material such as livers \& gizzards or products which not subjected to sufficient cooking are considered an important source for salmonella infection. Poultry meat products manufactured in food factories apply good hygiene practices are free from salmonella contamination. Strategies to reduce salmonella levels on raw poultry should be undertaken to improve the safety of poultry products and reduce the incidence of human salmonellosis from poultry consumption.

\section{ACKNOWLEDGEMENTS}

The author is thankful to the Faculty of Veterinary Medicine, Aswan University for Financial Support.

\section{REFERENCES}

Alali, W.Q.; Gaydashov, R.; Petrova, E.; Panin, A.; Tugarinov, O.; Kulikovski, A.; Mamleeva, D.; Walls, I. and Doyle, M.P. (2012): Prevalence of Salmonella on retail chicken meat in Russian Federation. J. Food Prot, 75 (8): 1469-1473.

AOAC INTERNATIONAL (2000): Official Methods of Analysis, 17th ed., Methods 967.25967.28, 978.24, 989.12, 991.13, 994.04, and 995.20. AOAC INTERNATIONAL, Gaithersburg, MD.

Bennett, R.W.; Yeterian, M.; Smith, W.; Coles, C.M.; Sassaman, M. and McClure, F.D. (1986): Staphylococcus aureus identification characteristics and enterotoxigenicity. J. Food Sci., 5 (5): 1337-1339.

Bodhidatta, L.; Srijan, A.; Serichantalergs, O.; Bangtrakulnonth, A.; Wongstitwilairung, B.; McDaniel, P. and Mason, C.J. (2013): Bacterial pathogens isolated from raw meat and poultry compared with pathogens isolated from children in the same area of rural Thailand. Southest Asian J Trop Med Public Health, 44 (2): 259-272.

Busani, L.; Cigliano, A.; Taioli, E.; Caliguiri, V.; Chiavacci, L.; Di Bella, C.; Battisti, A.; Duranti, A.; Gianfranceschi, M.; Nardella, 
M.C.; Ricci, A.; Rolesu, S.; Tamba, M.; Marabelli, R. and Caprioli, A. (2005): Prevalence of Salmonella enteric and Listeria monocytogenes contamination in foods of animal origin in Italy. J. Food Prot, 68 (8): 1729-1733.

Chen, L.; Dubrawski, A.W.; Ray, S.; Baysek, M.; Kelley, L.; Dunham, A.; Huckabee, M.; Fedorke-Cray, P.J.; Jackson, C. and McGlinchey, B. (2008): Detecting linkage between human illness and Salmonella isolates in food using a new tool for spatiotemporal analysis of multi-stream data. AMIA Annu Symp Proc, 6: 900-905.

Dione, M.M.; Leven, M.; Garin, B.; Marcotty, T. and Geerts, S. (2009): Prevalence and antimicrobial resistance of Salmonella isolated from broiler farms, chicken carcasses and street-vended restaurants in Casamance, Senegal. J. Food Prot, 72 (11): 2423-2427.

Domingues, S.A. and Schaffner, D.W. (2009): Survival of Salmonella in processed chicken products during frozen storage. J. Food Prot, 72 (10): 2088-2092.

Donado-Godoy, P.; Clavijo, V.; Leon, M.; Tafur, M.A.; Gonzales, S.; Hume, M.; Alali, W.; Walls, I.; LO Fo Wong, D.M. and Doyle, M.P. (2012): Prevalence of Salmonella on retail broiler chicken meat carcasses in Colombia. J. Food Prot, 75 (6): 1134-1138.

Elben, D.R.; Barlow, K.E. and Naugle, A.L. (2006): U.S. Food safety and Inspection Service testing for Salmonella in selected raw meat and poultry products in the United States, 1998 through 2003: an establishment-level analysis. J. Food Prot, 69 (11): 2600-2606.

Ewing, W.H. (1986): Edwards and Ewing's Identification of Enterobacteriacae, 4th ed. Elsevier, New York.

Fearnley, E.; Raupach, J.; Lagala, F. and Cameron, $S$. (2011): Salmonella in chicken meat, eggs and humans; Adelaide, South Australia, 2008. Int. J. Food Microbiol, 146 (3): 219-227.

Franz, E.; van der Fels-Klerx, H.J.; Thissen, J. and van Asselt, E.D. (2012): Farm and Slaughterhouse characteristics affecting the occurrence of Salmonella and Campylobacter in the broiler supply chain. Poultry Science, 91: 2376-2381.

Hammack, T.S.; Amaguana, R.M. and Andrews, W.H. (2001): Rappaport-Vassiliadis medium for the recovery of Salmonella from foods with a low microbial load: Collaborative study. J. AOAC Int.84: (1) 65-83.

Hammack, T.S.; Amaguana, R.M.; June, G.A.; Sherrod, P.S. and Andrews, W.H. (1999): Relative effectiveness of selenite cystine broth, tetrathionate broth, and Rappaport-
Vassiliadis medium for the recovery of Salmonella from foods with a low microbial load. J. Food Prot. 62:16-21.

Hanning, I.B.; Nutt, J.D. and Ricke, S.C. (2009): Salmonellosis outbreaks in the United States due to fresh produce: sources and potential intervention measures. Foodborne pathog Dis., 6(6): 635-648.

June, G.A.; Sherrod, P.S.; Hammack, T.S.; Amaguana, R.M. and Andrews, W.H. (1995): Relative effectiveness of selenite cystine broth, tetrathionate broth, and RappaportVassiliadis medium for the recovery of Salmonella from raw flesh and other highly contaminated foods: Precollaborative study. J. AOAC Int. 78: 375-380.

June, G.A.; Sherrod, P.S.; Hammack, T.S.; Amaguana, R.M. and Andrews, W.H. (1999): Relative effectiveness of selenite cystine broth, tetrathionate broth, and RappaportVassiliadis medium for the recovery of Salmonella from raw flesh, highly contaminated foods, and poultry feed: Collaborative study. J. AOAC Int. 79: 1307-1323.

Khaitsa, M.L.; Kegode, R.B. and Doetkott, D.K. (2007): Occurrence of antimicrobial-resistant Salmonella species in raw and ready to eat turkey meat products from retail outlets in the Midwestern United States. Foodborne Pathog Dis, 4 (2): 517-525.

M'ikanatha, N.M.; Sandt, C.H.; Localio, A.R.; Tewari, D.; Rankin, S.C.; Whichard, J.M.; Altikruse, S.F.; Lautenbach, E.; Folster, J.P.; Russo, A.; Chiller, T.M.; Reynolds, S.M. and McDermott, P.F. (2010): Multidrug-resistant Salmonella isolates from retail chicken meat compared with human clinical isolates. Foodborne Pathog Dis, 7 (8): 929-934.

MacDougall, L.; Fyfe, M.; Mcintyre, L.; Paccagnella, A.; Cordner, K.; Kerr, A. and Aramini, J. (2004): Frozen chicken nuggets and strips - a newly identified risk factor for Salmonella Heidelberg infection in British Columbia, Canada. J. Food Prot, 67 (6): 1111-1115.

Madden, R.H.; Moran, L.; Scates, P.; McBride, J. and Kelly, C. (2011): Prevalence of Campylobacter and Salmonella in raw chicken on retail sale in the republic of Ireland. J. Food Prot, 74 (11): 1912-1916.

Moschonas, G.; Geornaras, I.; mStopforth, J.D.; Wach, D.; Woerner, D.R.; Belk, K.E.; Smith, G.C. and Sofos, J.N. (2012): Antimicrobials for reduction of Salmonella contamination in uncooked, surface-browned breaded chicken products. J. Food Prot., 75 (6): 1023-1028.

Much, P.; Pichler, J.; Kasper, S.S. and Allerberger, F. (2009): Foodborne outbreaks,Austria 
2007. Wien Klin Wochenschr., 12 (3-4): 77-85.

Nogrady, N.; Kardos, G.; Bistyak, A.; Turcsanyi, I.; Meszaros, J.; Galantai, Z.; Juhasz, A.; Samu, P.; Kaszanyitzky, J.E.; Paszti, J. and Kiss, I. (2008): Prevalence and characterization of Salmonella infantis isolates originating from different points of the broiler chicken-human food chain in Hungary. Int. J. Food Microbiol, 127 (1-2): 162-167.

Oloya, J.; Doetkott, D. and Khaitsa, M.L. (2009): Antimicrobial drug resistance and molecular characterization of Salmonella isolated from domestic animals, humans and meat products. Foodborne pathog Dis., 6(3): 273-284.

Oscar, T.P. (2013): Initial contamination of chicken parts with Salmonella at retail and crosscontamination of cooked chicken with Salmonella from raw chicken during meal preparation. J. Food Prot, 76 (1): 33-39.

Pang, J.C.; Chiu, T.H.; Helmuth, R.; Schroeter, A.; Guerra, B. and Tsen, H.Y. (2007): A pulsed field gel electrophoresis (PFGE) study that suggests a major world-wide clone of Salmonella enteric serovar Enteritidis. Int. J. Food Microbiol, 116 (3): 305-312.

Raufu, I.; Hendriksen, R.S.; Ameh, J.A. and Aarestrup, F.M. (2009): Occurrence and characterization of Salmonella Hiduddify from Chickens and poultry meat in Nigeria. Foodborne Pthog Dis, 6 (4): 425-430.

Rios, R.M.; Araya, R.P.; Fernandez, R.A.; Tognarelli, J.; Hormazabal, J.C. and Fernandez, O.J. (2009): Molecular subtyping of Salmonella enteric serotype Enteritidis in a post epidemic period. Rev. Med. Chil, 137 (1): 71-75.

Smadi, H.; Sargeant, J.M.; Shannon, H.S. and Raina, P. (2012): Growth and inactivation of Salmonella at low refrigerated storage temperatures and thermal inactivation on raw chicken meat and laboratory media: mixed effect meta-analysis. J. Epidemiol Glob Health, 2 (4): 165-179.

Smith, K.E.; Medus, C.; Meyer, S.D.; Boxrud, D.J.; Leano, F.; Hedberg, C.W.; Elfering, K.; Braymen, C.; Bender, J.B. and Danila, R.N. (2008): Outbreaks of Salmonellosis in Minnesota (1998 through 2006) associated with frozen, microwaveable, breaded, stuffed chicken products. J. Food Prot, 71 (10): 2153-2160.

Ta, Y.T.; Nguyen, T.T.; To, P.B.; Pham da, X.; Le, H.T.; Alali, W.Q.; Walls, I.; Lo Fo Wong,
D.M. and Doyle, M.P. (2012): Prevalence of Salmonella on chicken carcasses from retail markets in Vietnam. J. Food Prot, 75 (10): 1851-1854.

Toboldt, A.; Tietze, E.; Helmuth, R.; Fruth, A.; Junker, E. and Malorny, B. (2012): Human infections attributable to the D-tartaratefermenting variant of Salmonella enteric serovar Paratyphi B in Germany originate in reptiles and, on rare occasions, poultry. Appl Envirn Microbiol, 78 (20): 7347-7357.

Trajkovic-Pavlovic, L.M.; Popovic, M.B.; Novakovic, B.D.; Gusman-Pasterko, V.P.; Jevtic, M.R. and Mirilov, J.M. (2007): Occurrence of Campylobacter, Salmonella, Yersinia enterocolitica and Listeria monocytogenes in some retail food products in Novi Sad. Cent Eur J. Public Health, 15 (4): 167-171.

Van der Fels-Klerx, H.J.; Tromp, S.; Rijgersberg, H. and van Asselt, E.D. (2008): Application of a transmission model to estimate performance objectives for Salmonella in the broiler supply chain. Int. J. Food Microbiol, 128 (1): 22-27.

Vandeplas, S.; Dubois, D.R.; Beckers, Y.; Thonart, P. and Thewis, A. (2010): Salmonella in chicken: current and developing strategies to reduce contamination at farm level. J. Food Prot, 73 (4): 774-785.

Vindigni, S.M.; Srijan, A.; Wongstitwilairoong, B.; Marcus, R.; Meek., J.; Riley, P.L. and Mason, C. (2007): Prevalence of foodborne microorganisms in retail foods in Thailand. Foodborne Pathog Dis, 4 (2): 208-215.

Waters, A.E.; Content-Cuomo, T.; Buchhagen, J.; Liu, C.M.; Watson, L.; Pearce, K.; Foster, J.T.; Bowers, J.; Driebe, E.M.; Engelthaler, D.M.; Keim, P.S. and Price, L.B. (2011): Multidrug-Resistant Staphylococcus aureus in US Meat and Poultry. CID, 52: 1-4.

White, P.L.; Naugle, A.L.; Jackson, C.R.; FedorkaCray, P.J.; Rose, B.E.; Pritchard, K.M.; Levine, P.; Saini., P.K.; Schroeder, C.M.; Dreyfuss, M.S.; Tan, R.; Holt, K.G.; Harman, J. and Buchanan, S. (2007): Salmonella Enteritidis in meat, poutry and pasteurized egg products regulated by the U.S. Food Safety and Inspection Service, 1998 through 2003. J. Food Prot, 70 (3): 582-591.

Williams and Wilkins (1984): Subject Le Minor L. Genus III Salmonella. In: Krieg NR, Holt JG, Editors. Bergey"s Manual of Systematic Bacteriology, vol. 1, Baltimore, P. 427. 


\title{
مدى حدوث ميكروب السالمونيلا فى منتجات لحوم الدواجن
}

\author{
محمـد كرمسى
}

Email: Karmy99@yahoo.com, mkarmi@aswu.edu.eg

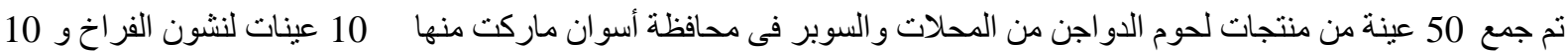

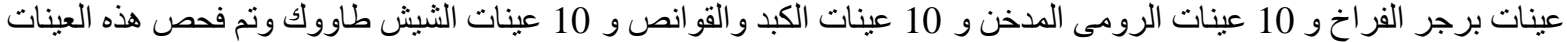

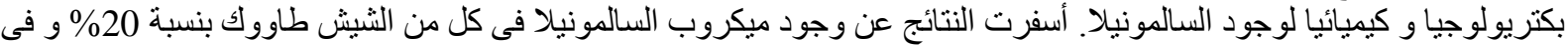

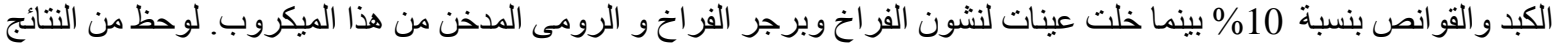

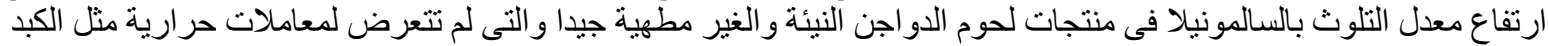

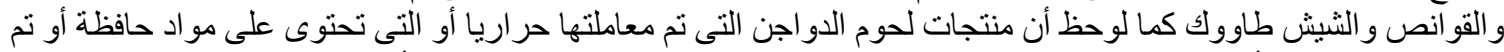

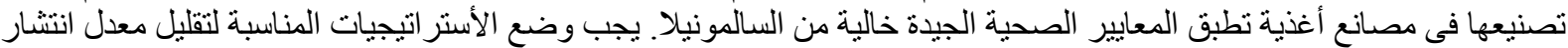

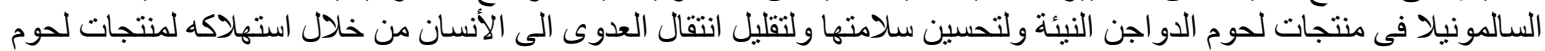

